УДК 82I.I6I.I

ББК $83.3(2 \mathrm{Poc}=\mathrm{Pyc}) 6$
РЕЦЕНЗИЯ НА ИЗДАНИЕ:

ЗОЛОТАРЕВ А.А. САМРО SANTO

МОЕЙ ПАМЯТИ: МЕМУАРЫ.

ХУДОЖЕСТВЕННАЯ ПРОЗА.

СТИХОТВОРЕНИЯ. ПУБЛИЦИСТИКА.

ФИЛОСОФСКИЕ ПРОИЗВЕДЕНИЯ.

ВЫСКАЗЫВАНИЯ СОВРЕМЕННИКОВ /

РЕДАКТОР-СОСТАВИТЕЛЬ В.Е. ХАЛИЗЕВ;

ОТВЕТСТВЕННЫЙ РЕДАКТОР

Д.С. МОСКОВСКАЯ. СПб.: РОСТОК, 2016. $960 \mathrm{c}$.

(C) 2018 г. А.В. Святославский Московский педагогический государственный университет, Москва, Россия

Дата поступления статьи: I7 января 2018 г.

Дата публикации: 25 июня 2018 г.

DOI: I0.22455/2500-4247-2018-3-2-330-339

Информация об авторе: Алексей Владимирович Святославский - доктор культурологии, профессор, Московский педагогический государственный университет, ул. Малая Пироговская, д. I/I, ІІ9435 г. Москва, Россия.

E-mail: pokrovi988@gmail.com.

Для цитирования: Святославский А.В. Рецензия на издание: Золотарев А.А. САМРО SANTO MOЕЙ ПАМЯТИ: Мемуары. Художественная проза. Стихотворения. Публицистика. Философские произведения. Высказывания современников / ред.-сост. В.Е. Хализев; отв. ред. Д.С. Московская. СПб.: Росток, 20I6. 960 с. // Studia Litterarum. 20I8. T. 3, № 2. C. 330-339. DOI: I0.22455/2500-4247-2018-3-2-330-339 


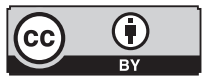

This is an open access article distributed under the Creative Commons Attribution 4.0 International (CC BY 4.0)

\section{ZOLOTAREV A.A. CAMPO SANTO OF MY MEMORY: MEMOIR. FICTION. POEMS. ESSAYS. PHILOSOPHICAL WORKS. OPINIONS OF CONTEMPORARIES. EDITED BY D.S. MOSKOVSKAYA AND V.E. HALIZEV. ST. PETERSBURG: ROSTOK PUBL., 2016. REVIEW}

\author{
(C) 20I8. A.V. Svyatoslavsky \\ Moscow Pedagogical State University, \\ Moscow, Russia \\ Received: January I7, 2018 \\ Date of publication: June 25, 2018
}

Information about the author: Alexey V. Svyatoslavsky, PhD in Cultural Studies, Professor, Moscow State Pedagogical University, Malaya Piragovskaya I/I, Moscow II9435, Russia.

E-mail: pokrovi988@gmail.com.

For citation: Svyatoslavsky A.V. Zolotarev A.A. Campo Santo of my Memory: Memoir. Fiction. Poems. Essays. Philosophical Works. Opinions of Contemporaries. Edited by D.S. Moskovskaya and V.E. Halizev. St. Petersburg: ROSTOK Publ., 20I6. Review. Studia Litterarum, 20I8, vol. 3, no 2, pp. 330-339. (In Russ.)

DOI: IO.22455/2500-4247-20I8-3-2-330-339 
Даже на современном обширном и разнообразном книжном рынке «Сатро Santo моей памяти» производит впечатление уникального издания. Том объемом без малого в тысячу страниц включил в себя так много, что можно заранее позавидовать читателям и будущим почитателям Алексея Алексеевича Золотарева (I879-1950) - человека, который так много сделал для сохранения памяти о других, а сам оказался почти забытым, пока не взялся за возрождение памяти о нем коллектив специалистов из Института мировой литературы РАН во главе с доктором филологических наук В.Е. Хализевым и доктором филологических наук Д.С. Московской.

Обращает на себя внимание библиографическое описание издания, получившееся не характерно длинным: здесь и художественная проза 3олотарева, и его стихи, и публицистика, и философские произведения, и отрывки дневника, и письма, и воспоминания современников об Алексее Алексеевиче... И потому жанр книги с трудом поддается однозначному определению, что, впрочем, закономерно: А.А. Золотарев сам необыкновенно многогранен. Вообразив себе необходимость написать о нем краткую справочную статью словарно-биографического вида, тут же задумываешься, а что же поставить на первое место: писатель, или философ, или ученый-естествоиспытатель широкого профиля, или историк-краевед, или общественный деятель, или хранитель и охранитель памяти... - музейный работник, архивист-библиотекарь? И все это будет верно и справедливо.

Пытаясь ответить на поставленный вопрос, раскроем книгу с первой страницы. Редакторы-составители начали вводную статью с цитаты из самого Золотарева, писавшего об удивительных «чарах и власти места» над человеческой душой. Значит, все-таки, край, краеведение, литературная 
местнография, «душа местности», как сказал бы близкий соратник Золотарева Николай Павлович Анциферов, - вот ключевые понятия всей деятельности Золотарева.

Однако на первом плане - рамочное название книги - «Campo Santo моей памяти». И снова цитата из Золотарева, перенесшего имя старинного пизанского кладбища на свои труды по сохранению памяти об ушедших современниках. Пятнадцать рукописных тетрадей включили в себя 497 очерков-меморий о тех, кто был рядом с Золотаревым. Среди них - те, кто составил славу отечественной культуры XX в., как и те, над которыми нависла бы угроза забвения, если бы не «синодик» Золотарева. На самом деле число «упоминаний» значительно превосходит цифру 497, поскольку каждый очерк вовлекал в себя целый ряд сопутствующих лиц, а с ними - и событий... А значит, наряду с понятием места, отметим как второй знаковый для Золотарева концепт - память. «Эпиграфом к “Campo Santo”, - пишут В. Хализев и Д. Московская, - могла бы послужить запись на обложке восьмой тетради, многажды на разный лад повторенная в мемориальной книге писателя: “Забвение - страшный грех” [г, с. 44]. Добавим от себя, что эта фраза стала жизненным девизом Золотарева. «Вот пишу эти строки, - сетует он, - а сердце... сердце, мое старое истерзанное сердце сжимается мучительно от тоски, чуть не плачу одинокими слезами, как И.С. Тургенев приговаривал в холод и мрак зимней военной ноябрьской ночи: “Все они умерли... умерли...”

Удивительна - хотя и характерна для конца русского XIX в. - личная и творческая биография Золотарева. Выйдя из духовной среды (его отец широко известный и любимый паствой священник в Рыбинске), Алексей и сам начинает жизненный путь в знаменитой Киевской духовной Академии на радость родителям, мечтавшим, чтобы хотя бы один из сыновей пошел по стопам отца. Однако, немного не доучившись, уходит на естественное отделение Санкт-Петербургского университета, где увлекается революционной подпольной работой, приведшей его к тюремным заключениям и ссылке. По окончании ссылки в жизни Золотарева начинается период эмиграции - Париж, где он поступает в университет Сорбонны. Затем он переезжает в Швейцарию и, наконец, попадает в Италию, на остров Капри, где задумывает большую работу о Джордано Бруно. В дальнейшем - после путешествий по Италии и возвращения в Россию - он вновь дважды вер- 
нется на Капри, причем последний раз живет там целых три года в близком общении с М. Горьким, что, как вспоминал Золотарев впоследствии, «было особенно благоприятно» - для его литературной и общественно-культурной работы [I, с. 56]. Золотарев становится заметной фигурой каприйского горьковского литературного круга, получив от Горького путевку в большую литературу, когда тот способствовал публикации его первой повести «В старой Лавре» в сборнике товарищества «Знание» за г9о8 г.

События последующих войн и революций в России разворачивают вектор устремлений Золотарева от поиска радикальных политических путей обновления России ровно наоборот, - к кропотливой работе по сохранению связи с корнями русской культуры, с родной «отцовщиной» и «дедо́вщиной» - так он часто образно называет уходящую культуру родины. В г920-х гг. Золотарев - важнейший участник краеведческого движения в эпоху, которую С.О. Шмидт назвал «золотым веком» отечественного краеведения. Век этот, как известно, закончился разгромом этого самого массового и сердечного движения в России XX в., и Золотарев в числе многих оказался арестован теперь уже новой властью и опять, как в дореволюционные времена, отправлен в ссылку, но в куда более тяжелые условия. Впоследствии усилиями М. Горького эти условия удалось смягчить, по крайней мере настолько, чтобы не дать Алексею Алексеевичу погибнуть в гнилых северодвинских бараках, где он работал на рубке леса.

Жизнь Золотарева после освобождения была далека от материального благополучия, сопутствовавшего в I930-I940-е гг. ряду отечественных ученых и писателей. Навсегда он остался человеком бессемейным и безбытным, полностью погруженным в служение Родине. Приведем его слова, в которых сказалась его мечта превратить краеведение в краелюбие. «Сколько радости, сколько чувства - вот именно этого преображения мира, его просветления, пронизанности присносущным светом! - рождается во мне, когда я со своим посохом иду по западным окраинам родимого города, где уже взошли и цветут, и красуются, и плодоносят далее людские поколения, засеянные и только манившие к себе в годы моего детства и юности», - записывает в дневнике Золотарев в день Преображения Господня 6 (19) августа I942 г., в светлый престольный праздник главного Рыбинского собора [I, с. 445].

Золотарева нельзя упрекнуть в изоляционизме - исключительной привязанности к своей земле, напротив, в отличие от многих краеведов, за- 
нимавшихся исключительно своей «малой» родиной, интересы руководителя и вдохновителя рыбинского краеведения простирались далеко окрест к Ярославлю и Угличу, Новгороду и Переславлю, Киеву и Москве и наконец, к Парижу и Италии. И художественная проза Золотарева, представленная в рецензируемом издании четырьмя повестями, последовательно вовлекает читателя в чудесную, какую-то отчасти даже мистическую, атмосферу Киева («В Старой Лавре»), северной сибирской реки («На чужой стороне»), Парижа («Во едину от Суббот»), древней ярославской земли («По престолам»).

Проза Золотарева зачаровывает. Он представляется блестящим бытописателем и одновременно мастером великолепных пейзажей, в которых ощущается единство Вселенной как единство всего живого и даже того, что принято считать не живым - природные стихии, камни, предметы быта... В Золотареве-писателе проступает язычник, землепоклонник. Место, город, уголок природы у Золотарева не просто образуют фон действия, но участвуют в нем, вступают в живой диалог с героями. Героине повести «Во едину от Суббот» Ольге чудится, что «вьюга надевает на Париж белый смешной балахон, Париж упирается, барахтается, дурачится, точно капризное дитя» [I, c. 256]. Древняя Киево-Печерская Лавра является перед героями повести «В Старой Лавре» «точно умытая и разодетая» и улыбается им в тихом весеннем утре [I, с. 2I7]. «Экая благодать! - восклицает герой повести «По престолам» отец Виталий, - Солнца-то как богато! Теплынь-то, наряд какой на земле» и - благословляет лежащие перед ним луга [I, с. 28о]. Груне Афродитовой, героине этой же повести, чудится, будто «ветер, давний друг ее сердца, наконец пришел за ней - взять ее, закружить, унести с собой...» [I, с. 290].

Прозу Золотарева хочется назвать философской в самом высоком смысле этого слова, поскольку за картинами повседневности встают вечные вопросы человеческого духа - смысла земного существования и посмертного бытия. Продолжая традицию Н.С. Лескова, он выстраивает «историю русского духовенства как великолепную историю русского духа» [I, с. 47]. Монахи, священники, церковный люд, учащиеся духовных академий («академики») у Золотарева являют собой живые образы, далекие от догматизма, начетничества, аскетического отвращения к миру. «Академик» Ластомский («По престолам») склоняется к уходу в монастырь, чтобы отвергнуть 
суету и искушения мирской жизни, однако монах о. Виталий уговаривает его жениться и получить приход в миру. Идя сельским лугом к родному кладбищу, к родимой отцовщине, Ластомский переживает смысл призыва монаха, отказавшегося от мира: «Ведь если бы не цвели вот также когда-то, в яркий купальский полдень, пышные травы, если бы не бежали по этому цветущему купавинскому лугу, как бежит впереди Санька с купавинскими девицами, те, что лежат сейчас на заболотском кладбище, не было бы и его, кто хочет уйти от мира, не любовался бы он миром...» [г, с. 285].

В образах его героев (широкий духом «академик» Платоныч, ищущая себя где-то между Россией и Парижем студентка Ольга Тугаринова, породнившая в своем сердце Париж и Москву мадам Гонья, польский ссыльнопоселенец умудренный старик Юлиуш, мятущийся духом иеромонах отец Виталий) ощутима причастность сложным психологическим типам Ф. Достоевского. Отчасти обрусевшая француженка мадам Гонья, она же по-русски Мария Львовна, рассуждает об исторической судьбе России: «Ведь вы, русские, какие-то... горькие. Хорошее это у вас слово, и горюете вы, как ни один народ в мире... всем существом своим... до безумия... до смерти...» [I, c. 254]. Неслучайны и аллюзии к другу и покровителю Золотарева Максиму Горькому, смысл литературного псевдонима которого уже почти стерся в современном культурном дискурсе, и о котором нам напомнил Золотарев.

Неповторима стилистика золотаревской прозы. Хотя, как отмечено в Примечаниях публикаторов к первой повести «В Старой Лавре», Золотарев, принеся вещь Горькому, извинялся за тяжесть стиля, мы можем отнести эту самокритику лишь на счет скромности и требовательности к себе автора. Легкий и красочный стиль повести - словно напоминание о северном угличском и ярославском узорочье храмов и летнем разноцветии тихой северной природы - чарует слух и воображение читателя. Роднясь с Горьким, автор наполняет многоглаголивыми цветистыми пассажами речь главного героя Платоныча. И все же главное впечатление от прозы Золотарева, - мысль о всепобеждающей силе жизни, которой исполнен весь сотворенный божественный мир. Так Ольга Тугаринова, героиня романа «Во едину от Суббот», «как мать, любила в каждом животном, в каждом растении, в каждом камне свое особенное, личное, - то, что есть в нем и чего нет и не может быть в другом, любила жизнь не в строгом единстве ее неизменяемых законов, а в неисчерпаемом разнообразии ее причудливых, 
вечно сменяющихся форм» [I, с. 257]. Конечно, это переживания не студентки Сорбонны, но самого Золотарева, чья проза, как отмечают авторы предисловия, всегда биографична.

Стиль Золотарева это даже не «мысле-слово», но непосредственное авторское чувство, чудесным образом вливающееся в душу читателя. Похоже, Золотарев знал свой секрет - свою способность играть созвучиями переживаний со слушателем: «Как песню, слушала девушка слова Юноши. Все в них было немного не так, не похоже на простую, ясную человеческую жизнь, как будто не мыслями, не логикой, а созвучиями своих чувств говорил Юноша...» [I, с. 199].

За всем жанровым многообразием включенных в рецензируемое издание материалов встает прекрасный образ Человека, отдавшего себя без остатка служению людям, тем, кто уже ушел, тем кто был рядом с автором в его непростой жизни, и тем, кто придут после. Этот образ особенно ценен сегодня, когда мы перешагнули границу XX в., когда собирание «литературных фактов» и биографий писателей «второго ряда» становится задачей уже не современников, но архивистов-библиографов.

В то же время, изданная книга ставит целый ряд вопросов, обращенных к науке о литературе. Один из них - о степени освоенности сокровищницы наших архивохранилищ. Из комментариев и предисловия к рецензируемой книге становится ясно, что документы фонда А.А. Золотарева в РГАЛИ, а также его обширная переписка с А.М. Горьким, В.Д. Бонч-Бруевичем, итальянскими писателями и литературоведами и др., его благоуханная проза «Тысячелетний Углич» и «Каприйские новеллы» далеко не освоены и ждут своего исследователя и публикатора. Сегодня мы наблюдаем острый всплеск интереса к эго-документам - воспоминаниям, дневникам, переписке 1920-1980-х гг., вызванный потребностью в индивидуализации и конкретизации общих представлений о нашей истории и культуре XX в. «Бытовая история революции - такова жанровая природа очерков “Кампо санто”. Золотарев выступает историком культуры, потому что стремится не только запечатлеть портрет человека, он восстанавливает имена его предков, указывает их социальный статус, фиксирует места их жизни, род их деятельности, их трудовые достижения, их вклад в окультуривание жизни местной. Он создает краеведческо-генеалогические очерки в ситуации, когда краеведение и генеалогия уничтожены, и делает это сознательно, сопрягая 
в единую цепь культуры то, что эпоха сознательно стремилась разорвать и уничтожить», - пишет ответственный редактор издания [2, с. 385].

В связи с наблюдением над формально-содержательной природой мемуарных очерков Золотарева возникает методологическая проблема жанрового описания и определения места в литературном процессе недооцененной и невостребованной академической наукой «персоналистской» ветви отечественной науки о литературе и литературном творчестве. «Вненаправленцы», объединенные «непоследовательностью» и бесконечным богатством сделанного, противостоят любым постулатам и программам творчества, которыми так богата «печатная» литература и официальная наука советского периода. Задача изучения и систематизации «вненаправленцев», поставленная некогда В.Е. Хализевым, становится еще более актуальной с появлением издания «избранного» трудов А.А. Золотарева. Остается надеяться, что ИМЛИ РАН не ограничится этим изданием наследия писателя и продолжит свой подвижнический труд по воскрешению нашей исторической памяти, возвращению нам забытых имен и текстов. 
Рецензии / А.В. Святославский

\section{Список литературы}

I Золотарев A.A. Campo santo моей памяти: Мемуары. Художественная проза. Стихотворения. Публицистика. Философские произведения. Высказывания современников / ред.-сост. В.Е. Хализев; отв. ред. Д.С. Московская. СПб.: Росток, 2016. $960 \mathrm{c}$.

2 Московская Д.С. Авторские стратегии легитимации вымысла в русской литературе 1920-I940-х гг. // Люди и тексты. Исторический альманах. М.: ИВИ РАН, 20I7. Вып. Іо: Историческая беллетристика. С. 366-395.

\section{References}

I Zolotarev A.A. Campo santo moej pamyati: Memuary. Xudozhestvennaya proza. Stixotvoreniya. Publicistika. Filosofskie proizvedeniya. Vyskazyvaniya sovremennikov [Campo Santo of my Memory: Memoir. Fiction. Poems. Essays. Philosophical Works. Opinions of Contemporaries], ed. by D.S. Moskovskaya and V.E. Halizev. St. Petersburg, Rostok Publ., 2016. 960 p. (In Russ.)

2 Moskovskaya D.S. Avtorskie strategii legitimacii vymysla v russkoj literature I920I940-x gg. [Authorial Strategies of Legitimizing Fiction in Russian literature of the I920S-I940's.] Lyudi i teksty. Istoricheskij al'manax [People and Texts. Historical Annual]. Moscow, IVI RAS Publ., 20I7, issue Io, pp. 366-395. (In Russ.) 